\title{
Utilization of bedded cattle confinement for organic manure of maize crop
}

\author{
Vania C. Mota ${ }^{1}$, Ednilton T. Andrade ${ }^{2}$, Sandra M. Pinto ${ }^{3}$, Luiz R. de Abreu ${ }^{3}$ \& Daniel F. Leite ${ }^{4}$ \\ ${ }^{1}$ Fundação Universidade Federal de Rondônia/Departamento de Matemática e Estatística. Ji-Paraná, RO, Brasil. E-mail:vaniamota33@gmail.com \\ (Corresponding author) - ORCID: 0000-0001-8838-718X \\ ${ }^{2}$ Universidade Federal de Lavras/Departamento de Engenharia Agrícola/Programa de Pós-Graduação em Engenharia Agrícola, Lavras, MG, Brasil. \\ E-mail: ednilton@deg.ufla.br - ORCID: 0000-0002-8448-8781 \\ ${ }^{3}$ Universidade Federal de Lavras/Departamento de Ciências dos Alimentos/Programa de Pós-Graduação em Ciências dos Alimentos, Lavras, MG, Brasil. \\ E-mail: sandra@dca.ufla.br - ORCID: 0000-0001-8431-6034; lrabreu@dca.ufla.br - ORCID: 0000-0002-8142-415X \\ ${ }^{4}$ Universidade Federal de Lavras/Departamento de Engenharia. Lavras, MG, Brasil. E-mail: daniel.leite@deg.ufla.br - ORCID: 0000-0003-3135-2933
}

\begin{abstract}
The use of organic wastes from housing systems in a compost bedded pack barn model could supply much of the fertiliser demand in the farm. Moreover, with the increase in food consumption from sustainable livestock, the use of compost generated in the farm itself becomes economically viable. This study aimed to evaluate the effect of organic manure from bedded cattle confinement applied at different moments on maize crop. The experiment was carried out in a randomized blocks with five treatments and five repetitions. The data were submitted to analysis of variance and the means were compared by Scott-Knott test at $\mathrm{p} \leq 0.05$. The treatments with addition of fresh compost and mature compost with nitrogen cover had higher production of maize shoot dry matter when compared to treatments without compost. For all variables analysed, the treatments with compost were superior to the other ones. The soil used for growing silage maize has improved considerably its chemical characteristics when the compost was applied. The use of bedding material compost from sheds as organic manure is recommended as a sustainable alternative in the reuse and treatment of waste from cattle confinement farm.
\end{abstract}

Key words: Zea mays L., dairy cattle, sustainable livestock, Compost Barn

\section{Aproveitamento da cama de confinamento de bovino para adubação orgânica do milho}

RESUMO: O uso de resíduos orgânicos, provenientes de sistema de confinamento no modelo 'Compost Barn' poderá suprir grande parte da demanda por adubo na propriedade. Além disso, com o aumento do consumo de alimentos oriundos da pecuária sustentável, a utilização de adubo gerado na própria propriedade se torna economicamente viável. Este trabalho teve como objetivo estudar o efeito da adubação orgânica proveniente da cama de confinamento de bovino aplicada em diferentes momentos no cultivo do milho. O delineamento experimental utilizado foi em blocos casualizados com cinco tratamentos e cinco repetições. Os dados foram submetidos à análise de variância e as médias foram comparadas pelo teste de Scott-Knott a $\mathrm{p} \leq 0,05$. Os tratamentos com adição de composto fresco e curtido com cobertura nitrogenada apresentaram maior produção de matéria seca da parte aérea do milho quando comparados com os tratamentos sem o uso de composto. Para todas as variáveis analisadas, os tratamentos que utilizaram o composto foram superiores aos demais tratamentos. O solo utilizado no cultivo do milho para silagem melhorou consideravelmente suas características químicas com a aplicação do composto. $\mathrm{O}$ aproveitamento do material de cama proveniente de galpões de compostagem, como adubo orgânico, é recomendável como uma alternativa sustentável no reuso e tratamento de dejetos da produção leiteira. Em longo prazo, o material da cama incorpora nutrientes ao solo, aumenta a produção agrícola e agrega valor à propriedade agrícola.

Palavras-chave: Zea mays L., bovino leiteiro, pecuária sustentável, Compost Barn 


\section{INTRODUCTION}

Recently, a new animal housing system known as compost-bedded pack barn (CBP), where the animals are stabled on a generally sawdust bed (Ferreira, 2016; Pilatti \& Vieira, 2017; Mota et al., 2017, 2018) has become preferred by producers. The main difference in the CBP housing system is in the animals' resting bed, that contains nitrogen derived from the urine and waste from cows housed in the CBP shed. Additionally, the bed contains carbon sources from sawdust, woodchips, chopped corn stover and peanut and coffee husks, among others (Leso et al., 2013; Galama et al., 2015).

The bed composting process in CBP systems is similar to that in compost piles. The aerobic decomposition is controlled by the microorganism action, and the stabilization of the crude organic matter is completed when forming humus. This final decomposition material is commonly used for agricultural purposes as fertiliser (Cotta et al., 2015).

The use of organic wastes, such as cow dung, represents a balanced way to provide nutrients to plants, as example in the maize crop for silage, which is used as dairy herd ration (Nascimento et al., 2008; Pescumo \& Igarasi, 2013).

With the increased concern about the environmental impacts generated by organic wastes from animal housing systems, interest in the composting process and recycling of these wastes have been stimulated (Cotta et al., 2015). The manure from the beds of dairy cattle from CBP housing systems could supply a large demand for fertilisers. Moreover, with the continuing increase in food consumption derived from sustainable livestock, the use of manure generated from the farm that could become economically viable. Based on the above information, this work aimed to study the effect of organic manure from bedded cattle confinement applied at different moments on maize crop.

\section{Material ANd Methods}

The study was performed in a greenhouse at the Universidade Federal de Lavras (UFLA), in the Southern region of the state of Minas Gerais, Brazil, at $21^{\circ} 14^{\prime} \mathrm{S}$ and $45^{\circ} 0^{\prime} \mathrm{W}$, and altitude of $918 \mathrm{~m}$. The regional climate is Cwa, with a dry winter and rainfall predominant in the summer, a total average annual rainfall of $1530 \mathrm{~mm}$ and an annual average temperature of $19.4^{\circ} \mathrm{C}$ (Dantas et al., 2007).

The experiment was conducted between November 2016 and February 2017. The average maximum and minimum temperatures were 29.3 and $18.4{ }^{\circ} \mathrm{C}$, respectively and the average external relative humidity was $72.8 \%$ in the greenhouse during the experimental period.

The experimental design was a randomized block design with five treatments and five repetitions, totalling 25 experimental plots. The treatments used in the experiment were as following: Treatment TM - Fresh compost added to the pot 15 days before sowing, with nitrogen topdressing; Treatment TC - Compost matured for 30 days and added to the pot on the day of sowing, with nitrogen topdressing; Treatment TF - Fresh compost added to the pot on the day of sowing, with nitrogen topdressing; Treatment TL - Without compost and with nitrogen topdressing (conventional); Treatment Control - Without both nitrogen topdressing and compost.

The experimental unit consisted of one plant in each pot with capacity of $15 \mathrm{dm}^{3}$, filled with a mixture of soil and washed sand in a 3:1 ratio (Guareschi et al., 2013). The pots were irrigated daily until reaching field capacity and were kept in a green house.

The soil used for cultivation was classified as an Ultisol having a clayey texture, with $70 \mathrm{dag} \mathrm{kg}^{-1}$ clay, $4 \mathrm{dag} \mathrm{kg}^{-1}$ silt and $26 \mathrm{dag} \mathrm{kg}^{-1}$ sand in the depths between 0 and $0.20 \mathrm{~m}$, located in a ravine area on the campus of the Universidade Federal de Lavras.

The chemical analysis of the soil presented the following result: $6.0 \mathrm{pH}$ in $\mathrm{H}_{2} \mathrm{O}, 6.08 \mathrm{mg} \mathrm{dm}^{-3}$ of $\mathrm{K}, 1.63 \mathrm{mg} \mathrm{dm}^{-3}$ of $\mathrm{P}$, $1.0 \mathrm{cmol}_{c} \mathrm{dm}^{-3}$ of Ca, $0.48 \mathrm{cmol}_{c} \mathrm{dm}^{-3}$ of $\mathrm{Mg}$ and $0.10 \mathrm{cmol}_{c} \mathrm{dm}^{-3}$ of Al. Additionally, the $\mathrm{H}+\mathrm{Al}$ (extractor: SMP) was $2.96 \mathrm{cmol} \mathrm{dm}^{-3}$, the effective cation exchange capacity [CEC (t)] was $1.65 \mathrm{cmol}_{c} \mathrm{dm}^{-3}$ and the cation exchange capacity at $\mathrm{pH} 7.0 \mathrm{H}_{2} \mathrm{O}$ [CEC (T)] was $4.51 \mathrm{cmol}_{\mathrm{c}} \mathrm{dm}^{-3}$. The exchangeable bases (SB) value was $1.55 \mathrm{cmol}_{c} \mathrm{dm}^{-3}$, the saturation base index $(\mathrm{V})$ was $34.27 \%$, the aluminium saturation index was $6.06 \%$, the organic matter (OM) was $1.09 \mathrm{dag} \mathrm{kg}^{-1}$ and the remaining phosphorus (P-Rem) was $4.86 \mathrm{mg} \mathrm{L}^{-1}$. Furthermore, $\mathrm{Cu}$ was $1.05 \mathrm{mg} \mathrm{dm}^{-3}$, $\mathrm{Zn}$ was $0.46 \mathrm{mg} \mathrm{dm}^{-3}, \mathrm{Mn}$ was $3.81 \mathrm{mg} \mathrm{dm}^{-3}$, Fe was $20.28 \mathrm{mg} \mathrm{dm}^{-3}$ and S was $104.65 \mathrm{mg} \mathrm{dm}^{-3}$.

The manure used in the experiment was obtained from a compost bedded pack barn (CBP) housing for dairy cattle located on a rural property in the municipality of Três Corações, in the state of Minas Gerais, Brazil. The physical and chemical characteristics of the compost are presented in Table 1. For the determination of N, the Kjeldahl method (Hoehne et al., 2016) was used, and the OM determination was based on the method proposed by Carmo \& Silva (2012).

The dose of $24.87 \mathrm{t} \mathrm{ha}^{-1}$ of CBP compost was applied manually 15 days before sowing the maize crop (Treatment - TM), while the other $24.87 \mathrm{t} \mathrm{ha}^{-1}$ doses of the compost (Treatment - TC and Treatment - TF) were applied during the sowing of the maize crop together with the chemical fertiliser application. Soil chemical correction was performed from the base saturation, and $1500 \mathrm{~g} \mathrm{dm}^{-3}$ of dolomitic limestone per pot was applied.

Table 1. Chemical characteristics of the compost from the feed system of dairy cattle in the compost bedded pack barn(CBP) model used in the treatments

\begin{tabular}{|crrr}
\hline Chemical & \multicolumn{3}{c|}{ Treatment } \\
\cline { 2 - 4 } characteristics (\%) & \multicolumn{1}{c|}{ TM } & \multicolumn{1}{c|}{ TC } & \multicolumn{1}{c|}{ TF } \\
\hline TS & 46.22 & 49.32 & 53.73 \\
pH in $\mathrm{H}_{2} \mathrm{O}$ & 9.43 & 9.05 & 9.11 \\
FMR & 18.49 & 28.98 & 15.69 \\
OM & 46.31 & 43.64 & 71.79 \\
TN & 3.50 & 1.80 & 1.90 \\
AN & 1.90 & 1.40 & 1.00 \\
C & 26.86 & 25.31 & 41.64 \\
C/N ratio & $8: 1$ & $14: 1$ & $22: 1$ \\
\hline
\end{tabular}

TS - Total solids; FMR - Fixed mineral residue, ashes; OM - Organic matter; TN Total nitrogen; AN - Ammonia nitrogen; C - Carbon, result on wet basis; Treatment TM - Fresh compost added to the pot 15 days before sowing, with nitrogen topdressing; Treatment TC - Compost matured for 30 days and added to the pot on the day of sowing, with nitrogen topdressing; Treatment TF - Fresh compost added to the pot on the day of sowing, with nitrogen topdressing 
The fertiliser application (NPK) at the sowing time in each pot corresponded to was $0.75 \mathrm{~g} \mathrm{dm}^{-3}$ of ammonium sulphate with the composition of $20 \%$ of $\mathrm{N}, 4.5 \mathrm{~g} \mathrm{dm}^{-3}$ of super simple phosphate in the composition of $20 \%$ of $\mathrm{P}$ and $2.25 \mathrm{~g} \mathrm{dm}^{-3} \mathrm{KCl}$ in the composition of $60 \%$ of $\mathrm{K}$. The guidelines of the $5^{\text {th }}$ Approximation of Minas Gerais (Alves et al., 1999) were considered when performing soil correction and nitrogen fertiliser application within topdressing, with recommendations of $90.0 \mathrm{~g} \mathrm{dm}^{-3} \mathrm{~N}$ divided into three portions. Ammonium sulphate with $20 \% \mathrm{~N}$ was used as the nitrogen source. At 15 days after emergence (DAE), the first nitrogen fertiliser application with a dose of $0.482 \mathrm{~g} \mathrm{dm}^{-3}$ per pot was carried out. The second and third nitrogen fertiliser applications occurred at 30 and 45 DAE.

The hybrid maize (Zea mays L.) cultivar Roundup Ready - NK 603 was sown on November 18, 2016, with three seeds per pot at a depth of $0.05 \mathrm{~m}$. Plant emergence occurred on November 23, 2016. The thinning occurred at 7 DAE, leaving one plant per pot.

The following characteristics were evaluated at the maize silage point (14/2/2017): plant height (PLH), by measuring the vertical distance between the soil surface and the insertion point of the last leaf using a measuring tape, stem diameter (SD), measured with digital caliper at $0.03 \mathrm{~m}$ from the ground, number of leaves (NL), shoot dry mass (SDM), shoot fresh mass (SFM) and moisture on dry basis (DBM).

The plants were cut close to the ground, weighed and placed in plastic bags. They were identified and transferred to an over at $65^{\circ} \mathrm{C}$, until obtaining constant mass (MAPA, 2007). The, ear length with (ELWH) and without husk (ELWOUTH), measured by a millimetre ruler, ear diameter with (EDWH) and without husk (EDWOUTH), measured with tachymeter.

The chemical analysis of the soil was performed after maize harvesting. In this analysis, a composite sample for the repetition was taken from 0 to $0.10 \mathrm{~m}$ depth that were sent to the Laboratory of Soil Analysis of the UFLA. The results were compared with the soil chemical characteristics determined prior to the installation of the experiment.

Initially, the basic assumptions of analysis of variance were verified. The Shapiro-Wilk test was applied to assess the data normality, the Hartley's test was used to determine the variance homogeneity and the residual analysis was used to examine the data independence (Banzatto \& Kronka, 2015). Subsequently, the data were submitted to analysis of variance and the means compared by the Scott-Knott test. A 0.05 probability for all tests mentioned was considered. The analyses were performed in R software (R Core Team, 2016) and SISVAR (Ferreira, 2011).

\section{Results AND Discussion}

There were significant differences at $\mathrm{p} \leq 0.05$ among the treatments (Table 2).

The organic material derived from the dairy cattle bedding in the CBP model housing system favoured higher shoot dry matter (SDM) for the NK 603 hybrid cultivar when compared to the treatments without compost (Table 2). The mean SDM values for treatments TC, TF and TM were $0.43,0.42$ and 0.39 $\mathrm{kg}$, respectively. Thus, there was a greater availability of silage material and feed for dairy cows.

For all variables analysed, no significant difference was observed by the Scott-Knott test among the TF, TM and TC treatments, and the averages of these treatments were superior to the averages of the other treatments.

The effect of cow dung doses on maize has also been studied by Reina et al. (2010), who verified that ears and grains increased in size and mass as manure doses also increased.

Several studies have shown the positive and gradual effect of using organic manure, especially cow dung. This manure has been used for the cultivation of several crops, including common bean (Phaseolus vulgaris L.) (Martins et al., 2015), cackrey (Cucumis anguria) (Oliveira et al., 2014) and sweet potato (Ipomoea batatas) (Leonardo et al., 2014).

The reference values are consumption of $8.4 \mathrm{t}$ of woodchips and/or sawdust per cow per year and 12 tons of compost produced per cow per year. However, these numbers can vary widely among farms (Galama et al., 2015). With the huge availability of mature bedding material, it can be reused by farmers both in the organic manure for their agricultural crops and also for resale to other farms.

Table 3 shows the results of the soil chemical analysis at the $0-0.10 \mathrm{~m}$ layer, collected in the pots after 77 days of

Table 2. Plant height (PLH), stem diameter (SD), number of leaves (NL), shoot fresh matter (SFM), shoot dry matter (SDM), dry basis moisture (DBM), ear diameter with husk (EDWH), ear diameter without husk (EDWOUTH), ear length with husk (ELWH) and ear length without husk (ELWOUTH) for different treatments at the silage point, 77 days after maize germination

\begin{tabular}{lrrrrrr}
\hline \multicolumn{1}{c}{ Variables } & Treatment control & \multicolumn{1}{c}{ TL } & \multicolumn{1}{c}{ TF } & \multicolumn{1}{c}{ TC } & TM & CV (\%) \\
PLH $(\mathrm{m})$ & $1.71 \mathrm{~b}$ & $1.73 \mathrm{~b}$ & $2.25 \mathrm{a}$ & $2.28 \mathrm{a}$ & $2.21 \mathrm{a}$ & 8.42 \\
$\mathrm{SD}(\mathrm{mm})$ & $14.42 \mathrm{~b}$ & $12.31 \mathrm{~b}$ & $17.50 \mathrm{a}$ & $18.75 \mathrm{a}$ & $18.40 \mathrm{a}$ & 13.97 \\
$\mathrm{NL}$ & $11.40 \mathrm{~b}$ & $11.60 \mathrm{~b}$ & $12.50 \mathrm{a}$ & $12.60 \mathrm{a}$ & $12.80 \mathrm{a}$ & 12.18 \\
$\mathrm{SFM}(\mathrm{kg})$ & $0.68 \mathrm{~b}$ & $0.66 \mathrm{~b}$ & $1.39 \mathrm{a}$ & $1.50 \mathrm{a}$ & $1.39 \mathrm{a}$ & 21.85 \\
$\mathrm{SDM}(\mathrm{kg})$ & $0.19 \mathrm{~b}$ & $0.16 \mathrm{~b}$ & $0.42 \mathrm{a}$ & $0.43 \mathrm{a}$ & $0.39 \mathrm{a}$ & 25.06 \\
$\mathrm{DBM}\left(\mathrm{g} \mathrm{H}_{2} \mathrm{O}\right)$ & $2.55 \mathrm{a}$ & $3.04 \mathrm{~b}$ & $2.30 \mathrm{a}$ & $2.59 \mathrm{a}$ & $2.53 \mathrm{a}$ & 10.19 \\
EDWH $(\mathrm{mm})$ & $39.60 \mathrm{~b}$ & $41.30 \mathrm{~b}$ & $50.70 \mathrm{a}$ & $51.4 \mathrm{a}$ & $50.00 \mathrm{a}$ & 7.48 \\
EDWOUTH $(\mathrm{mm})$ & $35.30 \mathrm{~b}$ & $35.70 \mathrm{~b}$ & $44.80 \mathrm{a}$ & $44.00 \mathrm{a}$ & $43.90 \mathrm{a}$ & 9.65 \\
ELWH $(\mathrm{mm})$ & $170.00 \mathrm{~b}$ & $180.00 \mathrm{~b}$ & $233.00 \mathrm{a}$ & $227.00 \mathrm{a}$ & $219.00 \mathrm{a}$ & 10.88 \\
ELWOUTH $(\mathrm{mm})$ & $128.00 \mathrm{~b}$ & $116.00 \mathrm{~b}$ & $173.00 \mathrm{a}$ & $178.00 \mathrm{a}$ & $187.00 \mathrm{a}$ & 17.33 \\
\hline
\end{tabular}

Means followed by the same letters in the row do not differ by Scott-Knott test at $\mathrm{p} \leq 0.05$; Treatment Control - Without both nitrogen topdressing and compost; Treatment TL Without compost and with nitrogen topdressing (conventional); Treatment TF - Fresh compost added to the pot on the day of sowing, with nitrogen topdressing; Treatment TM - Fresh compost added to the pot 15 days before sowing, with nitrogen topdressing; Treatment TC - Compost matured for 30 days and added to the pot on the day of sowing, with nitrogen topdressing; CV - Coefficient of variation 
Table 3. Values of soil chemical characteristics 77 days after maize planting for different treatments

\begin{tabular}{lr|rrrrr}
\hline & $\begin{array}{r}\text { Treatment } \\
\text { control }\end{array}$ & \multicolumn{1}{c}{ TL } & TF & \multicolumn{1}{c|}{ TC } & TM & \multicolumn{1}{c|}{ CV } \\
$(\%)$
\end{tabular}

Means followed by the same letter in the row do not differ at $\mathrm{p} \leq 0.05$ by the Scott-Knott test; Treatment Control - Without both nitrogen topdressing and compost; Treatment TL - Without compost and with nitrogen topdressing (conventional); Treatment TF - Fresh compost added to the pot on the day of sowing, with nitrogen topdressing; Treatment TM - Fresh compost added to the pot 15 days before sowing, with nitrogen topdressing; Treatment TC - Compost matured for 30 days and added to the pot on the day of sowing, with nitrogen topdressing; $\mathrm{CV}$ - Coefficient of variation

maize sowing, when the maize was at its silage point. The $\mathrm{pH}$ levels for the TM and TC treatments were higher than those of other treatments.

The concentrations of $\mathrm{K}, \mathrm{P}, \mathrm{Ca}, \mathrm{Mg}$ and $\mathrm{S}$ were superior for the TM treatment, followed by the TF, TC and TL treatments compared to the control (Table 3). The P concentration was higher for the treatments that received the compost compared to $\mathrm{TL}$ and the treatment control. Higher $\mathrm{P}$ concentration was verified in all treatments, in comparison with its initial value $\left(1.63 \mathrm{mg} \mathrm{dm}^{-3}\right)$. The concentrations of $\mathrm{Ca}$ and $\mathrm{Mg}$ were superior in the TC, TM, TF and TL treatments in comparison to the treatment without compost. Increases of $\mathrm{Ca}, \mathrm{Mg}$ and $\mathrm{S}$ concentrations in the soil to which fertiliser had been applied were also verified.

The $\mathrm{S}$ concentration, aluminium $\mathrm{P}-\mathrm{Rem}$ and $\mathrm{H}+\mathrm{Al}$ were similar in all treatments. However, comparing the values with the initial results, there was a decrease in aluminium content and an increase in the P-Rem. The mean $\mathrm{H}+\mathrm{Al}$ values were similar, with a slight decrease compared to the initial value of the soil. CEC ( $\mathrm{t}$ ) and CEC (T) were verified in the treatments with compost application (Table 3 ).

Similar results were found by Oliveira et al. (2014), who verified increase of CEC ( $\mathrm{t}$ ) and CEC (T) as a function of the application of manures to lettuce cultivation in a controlled environment. The authors relate this increase to the lesser loss by mineralization with organic matter.

The initial SB and $\mathrm{V}$ values were $1.55 \mathrm{cmol}_{c} \mathrm{dm}^{-3}$ and $34.27 \%$, respectively. When compared to the mean results in Table 3, there was an increase in these values. It was observed that the mean values of $\mathrm{SB}$ and $\mathrm{V}$ in $\mathrm{TC}, \mathrm{TM}$ and $\mathrm{TF}$ treatments did not differ and were higher than TL and the control treatments.

A reduction of the aluminium saturation index (\%) was observed, and the control treatment showed a higher value when compared to the other treatments.

The concentrations of $\mathrm{OM}$ increased for the three treatments in which CBP bedding material was applied at different moments, in comparison to soil OM value at the beginning of the experiment, and did not differ for these treatments and were higher than the values obtained in TL and control treatments (Table 3).

The $\mathrm{Fe}, \mathrm{Zn}$ and $\mathrm{Cu}$ micronutrient concentrations showed no significant difference in the TC, TM and TF treatments and were higher for TL and control treatments. The Mn concentration increased in all treatments and was higher in the TM and TF treatments, compared to initial values.

In general, improvement in soil fertility was verified by the end at 77 days after maize germination. According to Abreu Júnior et al. (2005), the fundamental effects caused by the disposal of organic wastes in agriculture are directly related to the increase in soil OM over successive applications.

Based on the above, there is a need for technologies that make it possible to increase crop yield, while seeking an ecologically sustainable and low-cost farming system. Therefore, the use of wastes from cattle housing systems such as the CBP model adds value to the producer and to the product, besides providing farming-livestock integration. It is a natural resource available on milk-producing farms.

\section{Conclusions}

1. The treatments TC - Compost matured for 30 days and added to the pot on the day of sowing, with nitrogen topdressing, TF - Fresh compost added to the pot on the day of sowing, with nitrogen topdressing and TM - Fresh compost added to the pot 15 days before sowing, with nitrogen topdressing showed higher shoot dry matter production and all growing variables for maize when compared to treatments without the use of compost.

2. The soil used in maize crop for silage considerably improved its chemical characteristics with the application of compost from the housing system for dairy cattle in compost bedded pack barn model, which can be used without maturation. 


\section{ACKNOWLEDGements}

The authors thank the Coordenação de Aperfeiçoamento de Pessoal de Ensino Superior (CAPES, Brazil) for financial support, the Departamento de Engenharia Agrícola da Universidade Federal de Lavras (UFLA) for the green house used for the experiments and the Departamento de Ciências de Alimentos da UFLA, setor de Laticínios for assistance with the physical and chemical analyses.

\section{Literature Cited}

Abreu Júnior, C. H.; Barreto, A. E.; Muraoka, T.; Kiehl, J. de C. Uso agrícola de resíduos orgânicos potencialmente poluentes: Propriedades químicas do solo e produção vegetal. Tópicos Especiais em Ciência do Solo, v.4, p.391-470, 2005.

Alves, V. M. C.; Vasconcellos, C. A.; Freire, F. M.; Pitta, G. V. E.; França, G. E. de; Rodrigues Filho, A.; Araújo, J. M. de; Vieira, J. R.; Loureiro, J. E. Milho. In: Ribeiro, A. C.; Guimaraes, P. T. G.; Alvarez V., V. H. (eds.). Recomendação para o uso de corretivos e fertilizantes em Minas Gerais: Quinta aproximação. Viçosa: Comissão de Fertilidade do Solo do Estado de Minas Gerais, 1999. p.314-316.

Banzatto, D. A.; Kronka, S. do N. Experimentação agrícola. 4.ed. Jaboticabal: FUNEP, 2015. 237p.

Carmo, D. L. do; Silva, C. A. Métodos de quantificação de carbono e matéria orgânica em resíduos orgânicos. Revista Brasileira de Ciência do Solo, v.36, p.1211-1220, 2012. http://dx.doi. org/10.1590/S0100-06832012000400015

Cotta, J. A. de O.; Carvalho, N. L. C.; Brum, T. da S.; Rezende, M. O. de O. Compostagem versus vermicompostagem: Comparação das técnicas utilizando resíduos vegetais, esterco bovino e serragem. Engenharia Sanitária e Ambiental, v.20, p.65-78, 2015. http:// dx.doi.org/10.1590/S1413-41522015020000111864

Dantas, A. A. A.; Carvalho, L. G. de; Ferreira, E. Classificação e tendências climáticas em Lavras, MG. Ciência e Agrotecnologia, v.31, p.1862-1866, 2007. http://dx.doi.org/10.1590/S141370542007000600039

Ferreira, D. F. Sisvar: A computer statistical analysis system. Ciência e Agrotecnologia, v.35, p.1039-1042, 2011. https://doi.org/10.1590/ S1413-70542011000600001

Ferreira, R. A. Maior produção com melhor ambiente para aves, suínos e bovinos. Viçosa: Aprenda Fácil, 2016. 526p.

Galama, P. J.; Boer, H. C. de; Dooren, H. J. C. van; Ouweltjes, W.; Driehuis, F. Sustainability aspects of ten bedded pack dairy barns in The Netherlands. Wageningen: Livestock Research, 2015. 83p.

Guareschi, R. F.; Silva, A.; Silva Junior, H. R. da; Perin, A.; Gazolla, P. R. Adubação orgânica na produção de biomassa de milho em Latossolo de cerrado. Global Science and Technology, v.6, p.66-73, 2013. http://dx.doi.org/10.14688/1984-3801.v06n02a08
Hoehne, L.; Santos, F. dos; Stülp, S.; Tischer, J. S.; Schneider, F. A. Avaliação das técnicas de determinação de nitrogênio por cromatografia iônica (IC) e por teor de nitrogênio total (TN) por quimiluminescência. Tecno-Lógica, v.20, p.9-13, 2016. http:// dx.doi.org/10.17058/tecnolog.v20i1.6230

Leonardo, F. de A. P.; Oliveira, A. P. de; Pereira, W. E.; Silva, O. P. R. da; Barros, J. R. A. Rendimento da batata-doce adubada com nitrogênio e esterco bovino. Revista Caatinga, v.27, p.18-23, 2014.

Leso, L.; Uberti, M.; Morshed, W.; Barbari, M. A survey of Italian compost dairy barns. Journal of Agricultural Engineering, v.44, p.120-124, 2013. https://doi.org/10.4081/jae.2013.282

MAPA - Ministério da Agricultura, Pecuária e Abastecimento. Manual de métodos analíticos oficiais para fertilizantes minerais, orgânicos, organominerais e corretivos. Brasília: MAPA, 2007. 141p.

Martins, J. D. L.; Moura, M. F. de; Oliveira, J. P. F. de; Oliveira, M. de; Galindo, C. A. F. Esterco bovino, biofertilizante, inoculante e combinações no desempenho produtivo do feijão comum. Revista Agro@mbiente On-line, v.9, p.369-376, 2015. http:// dx.doi.org/10.18227/1982-8470ragro.v9i4.2583

Mota, V. C.; Campos, A. T.; Damasceno, F. A.; Resende, E. A. de M.; Rezende, C. P. do A.; Abreu, L. R. de; Vareiro, T. Confinamento para bovinos leiteiros: Histórico e características. Pubvet, v.11, p.433-442, 2017. https://doi.org/10.22256/pubvet.v11n5.433-442

Mota, V. C.; Damasceno, F. A.; Leite, D. F. Fuzzy clustering and fuzzy validity measures for knowledge discovery and decision making in agricultural engineering. Computers and Electronics in Agriculture, v.150, p.118-124, 2018. https://doi.org/10.1016/j. compag.2018.04.011

Nascimento, W. G. do; Prado, I. N. do; Jobim, C. C.; Emile, J. C.; Surault, F.; Huyghe, C. Valor alimentício das silagens de milho e de sorgo e sua influência no desempenho de vacas leiteiras. Revista Brasileira de Zootecnia, v.37, p.896-904, 2008. https:// doi.org/10.1590/S1516-35982008000500018

Oliveira, A. P. de; Silva, O. P. R. da; Bandeira, N. V. da S.; Silva, D. F. da; Silva, J. A.; Pinheiro, S. M. G. Rendimento de maxixe em solo arenoso em função de doses de esterco bovino e biofertilizante. Revista Brasileira de Engenharia Agrícola Ambiental, v.18, p.1130-1135, 2014. https:// doi.org/10.1590/1807-1929/agriambi.v18n11p1130-1135

Pescumo, D. P.; Igarasi, M. S. Híbridos de milho e sorgo para silagem na alimentação de bovinos leiteiros. Pubvet, v.7, p.420-426, 2013. https://doi.org/10.22256/pubvet.v7n6.1513

Pilatti, J. A.; Vieira, F. M. C. Environment, behavior and welfare aspects of dairy cows reared in compost bedded pack barns system. Journal of Animal Behaviour and Biometeorology, v.5, p.97-105, 2017. https://doi.org/10.31893/2318-1265jabb.v5n3p97-105

R Core Team R: A language and environment for statistical computing. Vienna: R Foundation for Statistical Computing, 2016. Available on: <https://www.R-project.org/>. Accessed on: May 2017.

Reina, E.; Afférri, F. S.; Carvalho, E. V. de; Dott, M. A.; Peluzio, J. M. Efeito de doses de esterco bovino na linha de semeadura na produtividade de milho. Revista Verde de Agroecologia e Desenvolvimento Sustentável, v.5, p.158-164, 2010. 